\title{
Effect of planting pattern and organic nutrient sources on performance of maize in maize-cowpea Intercropping system
}

\author{
VIKRAM KUMAR, AK SINGH* AND LALA I P RAY
}

\begin{abstract}
A field experiment was conducted to evaluate the effect of planting pattern and organic nutrients sources on maize in an intercropping system with cowpea. The treatment consists of four planting pattern (Sole maize, Sole cowpea, 1:1 maize + cowpea and 2:2 paired row maize + cowpea) and four nutrient sources (inorganic, FYM, ambrosia weed biomass and $50 \%$ through FYM $+50 \%$ through ambrosia weed biomass) allocated to main and sub plots, respectively. Growth parameters of maize did not vary significantly due to planting various planting patterns with cowpea except for dry matter accumulation at harvest. Highest grain, stover and biological yield of maize was also reported from sole maize which was at par with paired row planted maize but significantly higher over the maize intercropped in 1:1 planting pattern with cowpea. All the growth parameters and yield attributes of maize also differed significantly due to application of various sources of plant nutrients except for plant height at 30 DAS, CGR and RGR during 30-60 DAS and cobs per plant and cob length. Maximum grain yield in maize was recorded from inorganic nutrient source which was at par with combined nutrient application through FYM and ambrosia. Protein content ingrain remain at par but nutrient uptake varied markedly and follow the trends of grain and biological yields both due to planting pattern and nutrient sources.
\end{abstract}

KEYWORDS

Maize, cowpea, intercropping, paired row, nutrient sources, Ambrossia
ARTICLE INFO

\begin{tabular}{lll}
\hline Received on & $:$ & $18 / 11 / 2020$ \\
Accepted on & $:$ & $14 / 01 / 2021$ \\
Published online & $:$ & $19 / 03 / 2021$ \\
\hline
\end{tabular}

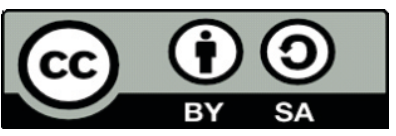

\section{INTRODUCTION}

$\mathrm{M}$ aize (Zea mays L.) is one among the oldest fully domesticated food plants, also known as miracle crop and queen of the cereals due to very high yield potential and wider adaptability. This is the third major food crop in India after rice and wheat (Singh et al., 2017), however, it is the second most important food crop in Meghalaya, with the area, production and productivity of 0.18 lakh ha, 0.27 lakh tons and 1.5 tha $^{-1}$, respectively (Anonymous, 2019). In the NEHR including the state of Meghalaya, maize productivity is much below than the national average and limited supply of plant nutrients is one among important reasons for this low yield level. Cowpea (Vigna unguiculata L.) is a multipurpose grain legume whose leaf and pods can be used as spinach and green bean while protein-rich seeds may be the substitute for meat. Since maize is planted at wider row spacing of $60-75 \mathrm{~cm}$, it provides enough opportunity to grow a short duration legume like cowpea as inter-crops in between two maize rows (Singh et al., 2013). Studies have shown that the productivity of maize in low fertile soils could be enhanced through the use of cowpea as intercrop as cowpea supplied some of the biologically fixed nitrogen to the associated cereals and maizelegume intercropping was more productive and less risky technology than the sole maize (Singh and Bhatt, 2013) .The technique of paired row planting in intercropping system is one way of accommodating the whole population of the base

School of Natural Resource Management, CPGS-AS (CAU-I), Umiam, Meghalaya, India

*Corresponding author email : adityakumar1972@yahoo.co.in crop and creating interspaces wide enough to accommodate one or two rows of intercrop. Several experiments revealedthat paired row planting of sorghum and maize for intercropping with different legumes gave similar yield as their normal spaced planting (Palaniappan and Ramaswamy, 1975). In context of hill farmers, present day requirement of plant nutrients through chemical fertilizers is neither desirable nor feasible. It is worthwhile to mention that the entire north eastern region is already recognized for promoting organic farming by Government of India, because of meagre use and apathy among farmers towards the use of inorganic chemicals like fertilizers and pesticides (Bharati et al., 2014). FYM and various forms of the composts are the traditional sources of fertilization under organic farming however; they became scarce and costly due to reduction in the cattle population and increase in farm mechanization. Hence, there is a need to find alternate organic sources of manuring for promoting organic crop production in this hilly region.Ambrosia artemisiifolia (Ambrosia or ragweed) is one among most wide spread noxious weed in NEH region especially during spring and pre Kharif season. The luxuriant vegetative growth of this weed extract large quantities of nutrient elements from the soil consists of $2.8 \%$ nitrogen, $0.73 \%$ phosphorus and $1.07 \%$ potassium in its tissues and can be used as organic source of plant nutrient supply. In view of the above, the present investigation was conducted to study the effect of various nutrient sources and planting pattern on performance of maize in an intercropping with cowpea. 


\section{MATERIALS AND METHODS}

A field experiment was conducted in Kharif season on research farm of the CPGS-AS (CAU-I), Umiam Meghalaya in split plot design with 3 replications. The treatment consists of four planting pattern (Sole maize, Sole cowpea, 1:1 maize + cowpea and 2:2 paired row maize + cowpea) and four nutrient sources (inorganic, FYM, ambrosia weed biomass and 50\% through FYM $+50 \%$ through ambrosia weed biomass) allocated to main and sub plots, respectively by using a fresh random number. The experimental field was sandy clay loam in texture with acidic in reaction ( $\mathrm{pH} 4.67)$. The soil was high in organic carbon, low in available nitrogen, and potassium but medium in available phosphorus.Total rainfall received during the cropping season was $831 \mathrm{~mm}$ and mean maximum and minimum temperature during the cropping season ranged from $28.58^{\circ} \mathrm{C}$ and $19.70^{\circ} \mathrm{C}$, respectively. The recommended fertilizer doses @ 80,60 and $40 \mathrm{~kg} \mathrm{ha}^{-1}$ and 20,60 and $40 \mathrm{~kg} \mathrm{ha}^{-1}$ of N, P and K were applied in sole crops of maize and cowpea respectively as per the standard agronomic process. In intercropping treatments, $50 \%$ of cowpea nutrient requirement was added in full requirement of maize. The doses of organic nutrient sources were adjusted equivalent to nitrogen requirement and all were applied 15 days in advance of sowing. Sowing was done on $15^{\text {th }}$ June of every year with plant to plant spacing of $20 \mathrm{~cm}$ for both the crops in the entire planting pattern. However, row spacing was adjusted as per the treatments. For paired row planting, two rows of cowpea were adjusted at normal spacing of $30 \mathrm{~cm}$ in the space available between two pairs of maize. In all cases, plant to plant spacing of $20 \mathrm{~cm}$ will be maintained for both the crops.For maize hybrid cultivar Vivek QPM-9 and for cowpea a local short duration cultivar wasgrown as per the recommended package of practices except for imposition of treatments. Observations on growth development, yield attributes and yield were recorded as per standard procedures. Data obtained from the experiment was analyzed by using the technique of ANOVA (Gomez and Gomez, 1984).

\section{RESULTS AND DISCUSSION}

\section{Growth and development}

Growth attended by maize was measured as plant height, leaf area index (LAI) and dry matter accumulation per plant (table 1), growth rates as crop growth rate (CGR) and relative growth rate (RGR) and attainment of developmental stages namely tasselling, silking and maturity by atleast $50 \%$ of crop plants (Table 2). Growth parameters tend to increase with advancement of crop age and their maximum value were recorded at maturity. Various planting pattern did not bring a significant difference in these parameters at any stage of observation except for dry matter accumulation at harvest when sole maize being at par with paired row planted maize recorded significantly higher plant dry weight per plant over 1:1 intercropped maize. Better availability of natural resources like aeration, solar radiation and optimum humidity combined with leguminous effect in paired row planting was possibly resulted in significantly high dry matter over 1:1 planted maize with cowpea. CGR and RGR remains at par due to planting pattern but differed significantly due to varied nutrient sources at all stages of observation except at par difference in both the growth rates at 30-60 DAS stages (table 2). As CGR is the per day increase in plant dry weight per unit land area, non-significant difference in dry matter accumulation in plants at all stages except at harvest was the reason for this trend in CGR (Table 1). RGR is the per day increase in plant dry weight over the already existing dry weight and had a decreasing trend with advancement of crop development. Since RGR is also dependent on dry matter accumulation in plants the similar reasoning of CGR may be cited here. Number of days taken to attend all three development stages under investigation remains at par both due to all planting pattern and different nutrient sources possibly because of similar

Table 1: Effect of planting pattern and nutrient sources on attainment of growth in Maize in maize-cowpea intercropping

\begin{tabular}{|c|c|c|c|c|c|c|c|c|c|}
\hline \multirow{3}{*}{ Treatment } & \multicolumn{3}{|c|}{ Plant height (cm) } & \multicolumn{3}{|c|}{ LAI } & \multicolumn{3}{|c|}{ Dry matter accumulation (g plant ${ }^{-1}$ ) } \\
\hline & 30 DAS & 60 DAS & Harvest & 30 DAS & 60 DAS & Harvest & 30 DAS & 60 DAS & Harvest \\
\hline & \multicolumn{9}{|c|}{ Planting pattern } \\
\hline Sole maize & 89.2 & 195.4 & 223.1 & 0.91 & 2.11 & 2.72 & 14.5 & 65.0 & 177.6 \\
\hline Maize + Cowpea & 87.0 & 2028 & 216.3 & 0.98 & 2.39 & 2.99 & 14.6 & 66.0 & 150.5 \\
\hline $\begin{array}{l}\text { (1:1) Maize + Cowpea } \\
\text { (Paired row) }\end{array}$ & 88.8 & 209.1 & 218.6 & 0.97 & 2.41 & 2.86 & 14.4 & 60.7 & 168.0 \\
\hline S.E.(m) \pm & 2.6 & 5.8 & 6.7 & 0.05 & 0.09 & 0.16 & 0.7 & 2.8 & 4.19 \\
\hline \multirow[t]{2}{*}{ C.D. $(\mathrm{P}=0.05)$} & NS & NS & NS & NS & NS & NS & NS & NS & 16.5 \\
\hline & \multicolumn{9}{|c|}{ Nutrient sources } \\
\hline RDF & 91.9 & 204.6 & 221.6 & 0.99 & 2.54 & 3.17 & 15.3 & 64.9 & 167.8 \\
\hline $100 \%$ FYM & 86.6 & 193.3 & 206.8 & 0.87 & 2.13 & 2.60 & 13.9 & 63.8 & 158.0 \\
\hline $100 \%$ Weed & 85.8 & 203.4 & 221.9 & 0.95 & 2.19 & 2.75 & 13.5 & 60.5 & 150.1 \\
\hline $\begin{array}{l}50 \% \text { Weed + } \\
50 \% \text { FYM }\end{array}$ & 89.0 & 208.4 & 227.0 & 1.01 & 2.35 & 2.91 & 15.2 & 66.6 & 185.5 \\
\hline S.E.(m) \pm & 1.6 & 3.1 & 3.8 & 0.03 & 0.07 & 0.04 & 0.5 & 1.4 & 4.4 \\
\hline C.D. $(\mathrm{P}=0.05)$ & NS & 9.3 & 11.4 & 0.09 & 0.22 & 0.13 & 1.4 & 4.3 & 13.1 \\
\hline
\end{tabular}


micro environment during the occurrence of these stages. These results are in the line of conformity with Alom et al. (2010).

However, all these three growth parameters varied significantly due to different nutrient sources except for plant height at 30DAS. At harvest, maximum plant height, LAI and dry weight per plant was recorded from the integrated nutrient application through FYM and Ambrossia green manuring which being at par with inorganic nutrient source, was significantly superior over the values recorded from sole nutrient application through FYM and Ambrossia green manuring alone. Inorganic nutrient treatment at 30 DAS recorded highest growth parameters due to adequately availability of plant nutrients from soluble fertilizer sources. However, with advancement of crop age better growth was associated with organic sources. Higher rate of dry matter in integrated application of FYM and weed biomass was attributed to more plant height, greater size of photosynthetic system as evidenced by leaf area and possibly higher rate of photosynthesis due to balanced availability of essential nutrients with favourable weather parameters. This trend in growth was possibly due to more availability of $\mathrm{N}, \mathrm{P}$ and $\mathrm{K}$ nutrients for crop uptake from organic nutrient sources because of slow and prolonged release from FYM and Ambrosia sources which may resulted in enhanced nutrient use efficiency due to favourable soil physical and biological conditions created by soil organic matter while some of the nutrients in inorganic plots were leached beyond root zone or lost as evaporation and run off or a part of orthophosphate ion got fixed with various forms of iron and aluminum in soil. Balyan et al. (2006), Joshi et al. (2013) and Mandal et al. (2014) also reported similar trends in maize growth and growth rates due to application of various organic nutrient sources over the inorganic nutrient source alone. The increased dry matter due to combine application of FYM and weed biomass also resulted in significantly higher CGR and RGR at 0-30 DAS and 60-harvest (Table 2) stages of crop growth when integrated application of FYM and Ambrosia being at par with recorded significantly more growth rates over sole nutrient application through Ambrossia weed biomass alone. This could be attributed to higher rate of dry matter production due to longer and balanced nutrient supply in the earlier two nutrientsources.Ayoola and Makinde, (2007) also reported similar results in growth rates of maize in an intercropping system with cowpea due to application of various nutrient sources.

\section{Yield attributes and yields}

Among yield attributes, Cobs plant ${ }^{-1}$ and test weight remained at par while cob length, grains $\operatorname{cob}^{-1}$ and grain weight plant varied significantly due to planting pattern.Paired row planted maize being at par with sole maize recorded significantly higher values of these parameters above the 1:1 intercropped maize with cowpea (Table 3). Better growth attended by the maize plantsin these two treatments was the reason for production of significantly more yield attributes in maize planted with these two plantnting patterns possiblydue to higher cell division and more translocation of photosynthates from source to sink.Grain yields in sole maize was at par with the paired row planted maize and both the treatments recorded their significant superiority for grain yield over 1:1 planting of maize with cowpea. Paired row planted maize recorded $18.6 \%$ more yield over 1:1 intercrop maize. Stover yield, biological yield and harvest index in

Table 2: Effect of planting pattern and nutrient sources on attainment of growth rate and development stages in Maize in maizecowpea intercropping

\begin{tabular}{|c|c|c|c|c|c|c|c|c|c|}
\hline \multirow[t]{2}{*}{ Treatment } & \multicolumn{3}{|c|}{ Crop growth rate $\left(\mathrm{mg} \mathrm{cm}^{-2} \mathrm{~d}^{1}\right)$} & \multicolumn{3}{|c|}{ Relative growth rate $\left(\mathrm{mg} \mathrm{g}^{-1} \mathrm{~d}^{-1}\right)$} & \multicolumn{3}{|c|}{ Days taken to } \\
\hline & $\begin{array}{r}0-30 \\
\text { DAS }\end{array}$ & $\begin{array}{l}30-60 \\
\text { DAS }\end{array}$ & $\begin{array}{l}60 \text { DAS- } \\
\text { Harvest }\end{array}$ & $\begin{array}{r}0-30 \\
\text { DAS }\end{array}$ & $\begin{array}{l}30-60 \\
\text { DAS }\end{array}$ & 60-Harvest & $\begin{array}{c}50 \% \\
\text { tasselling }\end{array}$ & $\begin{array}{c}50 \% \\
\text { silking }\end{array}$ & $\begin{array}{c}50 \% \\
\text { maturity }\end{array}$ \\
\hline & \multicolumn{9}{|c|}{ Planting pattern } \\
\hline Sole maize & 0.40 & 1.40 & 3.13 & 38.64 & 21.62 & 14.59 & 54.17 & 60.75 & 83.58 \\
\hline $\begin{array}{l}\text { Maize + Cowpea } \\
(1: 1)\end{array}$ & 0.41 & 1.43 & 2.35 & 38.60 & 22.00 & 11.89 & 53.58 & 60.08 & 84.58 \\
\hline $\begin{array}{l}\text { Maize + Cowpea } \\
\text { (Paired row) }\end{array}$ & 0.40 & 1.29 & 2.98 & 38.51 & 20.89 & 14.57 & 53.33 & 59.58 & 84.33 \\
\hline S.E. $(\mathrm{m}) \pm$ & 0.02 & 0.06 & 0.17 & 0.70 & 0.23 & 0.79 & 0.304 & 0.573 & 0.520 \\
\hline \multirow[t]{2}{*}{ C.D. $(\mathrm{P}=0.05)$} & NS & NS & NS & NS & NS & NS & NS & NS & NS \\
\hline & \multicolumn{9}{|c|}{ Nutrient sources } \\
\hline RDF & 0.43 & 1.38 & 2.86 & 39.34 & 20.96 & 13.65 & 54.00 & 60.56 & 83.89 \\
\hline $100 \%$ FYM & 0.39 & 1.39 & 2.62 & 38.05 & 22.07 & 13.07 & 53.89 & 59.56 & 83.78 \\
\hline $100 \%$ Weed & 0.37 & 1.30 & 2.49 & 37.59 & 21.70 & 13.12 & 53.44 & 59.89 & 84.44 \\
\hline $\begin{array}{l}50 \% \text { Weed + } \\
50 \% \text { FYM }\end{array}$ & 0.42 & 1.43 & 3.30 & 39.35 & 21.28 & 14.90 & 53.44 & 60.56 & 84.56 \\
\hline S.E.(m) \pm & 0.01 & 0.04 & 0.13 & 0.46 & 0.51 & 0.49 & 0.591 & 0.569 & 0.378 \\
\hline C.D. $(\mathrm{P}=0.05)$ & 0.04 & NS & 0.38 & 1.37 & NS & 1.47 & NS & NS & NS \\
\hline
\end{tabular}


maize follow the same trend of grain yield. Higher values of almost all the yield attributes in paired row planted maize and sole maize over the 1:1 intercropped maize-cowpea, due to attainment of better growth and higher mobilization of photosynthates towards sink(test weight) was responsible for this trend in grain yield and harvest index while significantly more dry weight per plant is attributed to differences in stover and biological yields as biological yield was the result of sum of grain and stover yield. Similar variation inyield attributes,yields and harvest index of maize due to different planting pattern in maize legume intercropping werealso reported by Padhi and Panigrahi (2006); Alhaji (2008)) and Gabatshele et al. (2012).

Yield attributes also varied significantly due to nutrient sources except for number of cobs per plant. Relatively higher but at par yield attributes were observed from inorganic and integrated nutrient application with Ambrosia grenn manuring and FYM which were significantly higher over the sole nutrient application thorugh FYM or Ambrossia alone. Grain yield recorded from inorganic nutrient source and combined application of FYM and Ambrossia green manuring was at par but significantly superior over the sole application of later two nutrientsources alone. Stover and biological yield followed the same trend of grain yield however, harvest index remained at par among all the nutrient sources. (Table 1 and 2). As a result, almost all yield attributes were significantly influence by integrated application of FYM and Ambrossia weed biomass (Table 3). Significantly high yield attributes due to attainment of significantly more growth in these two treatments over the sole nutrient application from either of FYM or Ambrossia green manuring alone due to attainment of significantly more growth and growth rates as discussed above was the main reason for significantly high grain yield in earlier two treatments. Reasons for significant variation in stover and biological yield which the same trends of grain yield could be attributed similarto the effect of planting pattern as discussed above. Balyan et al. (2006) and Joshi et al., (2013) also observed similar differences in yield attributes and yields of maize in maize-cowpea intercropping.

Table 3: Effect of planting pattern and nutrient sources on attainment of development stages, yield attributes and yield on maize in Maize-cowpea intercropping

\begin{tabular}{|c|c|c|c|c|c|c|c|c|c|}
\hline \multirow{3}{*}{ Treatment } & \multirow[b]{2}{*}{$\begin{array}{l}\text { Cobs } \\
\text { plant }^{-1}\end{array}$} & \multirow[b]{2}{*}{$\begin{array}{l}\text { Cob } \\
\text { length } \\
(\mathrm{cm})\end{array}$} & \multicolumn{3}{|c|}{ Yield attributes } & \multicolumn{4}{|c|}{ Yields $\left(\mathrm{t} \mathrm{ha}^{-1}\right)$} \\
\hline & & & $\begin{array}{c}\text { Grains } \\
\operatorname{cob}^{-1}\end{array}$ & Test wt. (g) & $\begin{array}{l}\text { Grain wt. } \\
\operatorname{cob}^{-1}(g)\end{array}$ & $\begin{array}{c}\text { Grain } \\
\text { yield } \\
\left(t \text { ha }^{-1}\right)\end{array}$ & $\begin{array}{c}\text { Stover } \\
\text { yield } \\
\left(\mathrm{t} \mathrm{ha}^{-1}\right)\end{array}$ & $\begin{array}{c}\text { Biological } \\
\text { yield } \\
\left(\mathrm{t} \mathrm{ha}^{-1}\right)\end{array}$ & $\begin{array}{c}\text { Harvest } \\
\text { Index } \\
(\%)\end{array}$ \\
\hline & \multicolumn{9}{|c|}{ Planting pattern } \\
\hline Sole maize & 1.05 & 23.94 & 472.17 & 208.29 & 93.21 & 5.37 & 7.60 & 12.97 & 41.45 \\
\hline Maize + Cowpea (1:1) & 1.05 & 20.18 & 404.67 & 193.32 & 85.11 & 4.25 & 6.27 & 10.52 & 40.47 \\
\hline $\begin{array}{l}\text { Maize + Cowpea } \\
\text { (Paired row) }\end{array}$ & 1.08 & 22.25 & 480.31 & 198.90 & 95.82 & 5.04 & 7.12 & 12.16 & 41.32 \\
\hline S.E.(m) \pm & 0.01 & 0.57 & 15.23 & 4.14 & 1.87 & 0.19 & 0.21 & 0.40 & 0.19 \\
\hline \multirow[t]{2}{*}{ C.D. $(P=0.05)$} & NS & 2.23 & 59.80 & NS & 7.33 & 0.73 & 0.84 & 1.57 & 0.733 \\
\hline & \multicolumn{9}{|c|}{ Nutrient sources } \\
\hline RDF & 1.10 & 22.25 & 481.91 & 217.18 & 103.54 & 5.40 & 7.74 & 13.13 & 41.12 \\
\hline $100 \%$ FYM & 1.05 & 21.07 & 420.73 & 195.36 & 82.53 & 4.16 & 6.02 & 10.18 & 40.70 \\
\hline $100 \%$ Weed & 1.02 & 22.07 & 435.72 & 191.63 & 89.19 & 4.85 & 7.16 & 12.00 & 40.40 \\
\hline $\begin{array}{l}50 \% \text { Weed + } \\
50 \% \text { FYM }\end{array}$ & 1.07 & 23.10 & 470.94 & 196.52 & 91.58 & 5.15 & 7.07 & 12.22 & 42.09 \\
\hline S.E. $(\mathrm{m}) \pm$ & 0.02 & 0.46 & 11.12 & 2.97 & 1.76 & 0.15 & 0.23 & 0.34 & 0.68 \\
\hline C.D. $(P=0.05)$ & NS & 1.35 & 33.04 & 8.82 & 5.21 & 0.45 & 0.69 & 1.01 & NS \\
\hline
\end{tabular}

\section{Protein content and nutrient uptake}

The N, P and K content in maize grains was remain at par both due to planting pattern and nutrient sources except for $\mathrm{P}$ content when pairedrow planted being at par with sole maize recorded significantly higher $P$ content in maize grain over 1:1 plantedintercrop maize. However, total uptake of N, P and K varied significantly due to both the factors of planting patterns and nutrient sources. Their at par uptake was recorded with sole and paired row planted maize and both these maize removed significantly higher nutrients over the maize planted as 1:1 intercropping with cowpea.At par $\mathrm{N}$ content in maize grains both due to planting pattern and nutrient sources was the reason for t par protein content due to both the factors as it is the result of multiplication of grain $\mathrm{N}$ content with 6.25(AOAC,2020).Uptake of any nutrient in a particular plant or its part could be attributed to a smaller extent for its content in the tissue and to the larger extent on dry matter yield.In present investigation, considerable high biological yield in paired row intercrop maize and sole maize over the 1:1 intercrop maize could be attributed to this 
Table 4: Effect of planting pattern and nutrient sources on protein content and uptake nutrient in maize in maize-cowpea intercropping

\begin{tabular}{l|cccc}
\hline & $\begin{array}{c}\text { Protein } \\
\text { content } \\
\text { Treatment }\end{array}$ & $\begin{array}{c}\text { N uptake } \\
\text { in } \\
\text { maize }\end{array}$ & $\begin{array}{c}\text { P uptake } \\
\text { in } \\
\text { maize }\end{array}$ & $\begin{array}{c}\text { K uptake } \\
\text { in } \\
\text { maize }\end{array}$ \\
\hline Planting pattern & & & & \\
\hline Sole maize & 9.52 & 120.97 & 22.92 & 68.97 \\
Maize + Cowpea (1:1) & 9.38 & 97.36 & 17.17 & 55.41 \\
Maize + Cowpea (2:2) & 9.51 & 115.48 & 23.64 & 63.41 \\
S.E.(m) \pm & 0.15 & 2.75 & 0.68 & 1.49 \\
C.D.(P=0.05) & NS & 10.80 & 2.65 & 5.87 \\
\hline Nutrient sources & & & & \\
\hline RDF & 9.47 & & & \\
100\% FYM & 9.53 & 123.44 & 22.69 & 72.29 \\
100\% weed & 9.48 & 94.82 & 17.24 & 52.60 \\
50\% weed + 50\% FYM & 9.40 & 111.48 & 22.86 & 62.46 \\
S.E.(m) \pm & 0.10 & 115.34 & 22.19 & 63.02 \\
C.D.(P=0.05) & NS & 3.49 & 0.82 & 2.20 \\
\hline
\end{tabular}

\section{REFERENCES}

Alhaji IH. 2008. Performance of some cowpea varieties under sole and intercropping with maize. African Research Review2 (3) : pp. 278-291.

Alom MS, Paul NKand Quayyum MA.2010. Production potential of different varieties of hybrid maize (Zea mays L.) with groundnut (Arachis hypogaea L.) Under intercropping system Bangladesh. J. Agril. Res.35 (1): 51-64.

Anonymous.2019.Handbook on Area, Production and Yield of Principal Crops in Meghalaya 2019. Department of Agriculture, GovernmentofMeghalaya. Shillong. Vol V, pp68.AOAC.2002. Official methods of analysis, International $17^{\text {th }}$ Edn. Gaithersburg (Ed). Association of Official Analytical Chemists, Virginia, USA.

Ayoola OT and Makinde EA.2007. Complementary organic and inorganic fertilizer application: influence on growth and yield of cassava/maize/melon intercrop with a relayed cowpea. Australian Journal of Basic and Applied Sciences1(3): 187-192.

Balyan JK, Singh P, Kumpawat BS and Jain LK.2006. Effect of integrated nutrient management on maize (Zea mays L.) growth and its nutrients uptake. Current Agriculture30 (1-2): 79 -82 .

Bharati RC, Singh KM, Chandra N and Singh AK.2014. Economic condition of eastern region of India -An statistical evaluation. Journal of AgriSearch1 (3):173-179.

Gabatshele M, Legwaila T, Marokane K and Mojeremane W.2012. Effects of Intercropping on the Performance of Maize and significant difference in nutrient uptake. Mandal et al. (2014) and Gabatshele et al. (2012) also observed similar trends for protein content and nutrient uptake in maize due to different planting pattern in an intercropping system.Significant variation in total uptake of N, P and K due to various nutrient sources could also be explained similar to planting pattern effect(Table 4). Balyan et al. (2006)and Joshi et al. (2013) also observed similar effect of nutrient sources on maize protein and nutrient uptake.

\section{CONCLUSION}

From the present investigation it could be concluded that paired row planting of maize is a better alternative to accommodate cowpea as an intercrop as maize yield was at par between the paired row planted intercrop maize and sole maize. Further, green manuring with Ambrosia weed biomass could partially substitute the requirement of traditional organic manure FYM as partial replacement of FYM through Ambrosia green leaf manure produced at par economic yield of maize as compare to maize plots treated with inorganic nutrient sources.

Cowpeas in Botswana. International Journal of Agriculture and Forestry2 (6): 307-310.

Gomez KA and Gomez AA. 1984. Statistical procedures for Agricultural research, 2nd edn. International Rice Research Institute, Los Banos, Philippines. John Willy and Sons, New York. pp. 324.

Joshi E, Nepalia V, Verma A and Singh D. 2013. Effect of integrated nutrient management on growth, productivity and economics of maize. Indian Journal of Agronomy 58 (3):434-436.

Mandal MK, Banerjee M, Banerjee H, Alipatra A and Malik GC. 2014. Productivity of maize (Zea Mays) based intercropping system during kharif season under red and lateritic tract of West Bengal. An International Quarterly Journal of Life Sciences (The Bioscan) 9 (1): 31-35.

Palaniappan SP and Ramaswamy R. 1975. Residual effect of atrazine applied to sorghum on succeeding crops, Madras Agricultural Journal63: 196-197.

Singh AK and Bhatt BP. 2013. Effects of foliar application of zinc on growth and seed yield of late-sown lentil. Indian J. Agril. Sci. 83 (6): 622-626.

Singh AK, Singh AK, Kumar R, Prakash V Sundaram PK and Yadav SK. 2017. Indian Cereals Saga: Standpoint and Way Forward. Journal of AgriSearch 4 (1): 1-10.

Singh AK, Singh KA, Bharati RC and Chadra N.2013.Response of intercrops and nutrient management on the performance of tobacco based intercropping system and assessment of system sustainability. Bangladesh J. Bot. 42(2):343-348.

Citation:

Kumar V, Singh A K and Ray LIP.2021.Effect of planting pattern and organic nutrient sources on performance of maize in maize-cowpea intercropping system. Journal of AgriSearch 8(1): 1-5 